\title{
FEATURES OF THE DEVELOPMENT OF BANKING INFORMATION SYSTEMS IN RUSSIA AND FOREIGN COUNTRIES
}

\author{
Lilia M. Yusupova ${ }^{1}$ \\ Tatyana V. Nikonova ${ }^{2}$ \\ Irina A. Kodolova ${ }^{3}$ \\ Mariya A. Musailova ${ }^{4}$
}

\begin{abstract}
One of the areas of activity in modern economy, where information technology value is traditionally high, is the financial and credit sphere. Computer banking networks provide a communication function and provide access to shared resources. Information systems of credit institutions allow to provide remote customer service. This article examines the peculiarities of banking information systems in Russia and abroad in two main areas: remote banking services and information technologies for the management of commercial banks. The authors have studied into the features of banking information systems in Russia and
\end{abstract}

abroad, and have characterized the above mentioned systems, outlined the current trends in the IT development in credit organizations of modern Russia. The research allowed the authors to drawa conclusion that information technologies play an important role in attracting new customers to banks and ensuring interaction with them.. Information banking technologies directly determine the credit organization's ability to develop business and improve internal processes and customer service systems. In this connection, the article suggests the further development of IT sphere as a factor of improving the quality of

\footnotetext{
${ }^{1}$ Kazan Federal University, Institute of Management, Economics and Finance, Kazan, 420008, Russia. Email address: kiak6@mail.ru.

${ }^{2}$ Kazan Federal University, Institute of Management, Economics and Finance, Kazan, 420008, Russia.Email address: kiak6@mail.ru

${ }^{3}$ Kazan Federal University, Institute of Management, Economics and Finance, Kazan, 420008, Russia.Email address: kiak6@mail.ru

${ }^{4}$ Kazan Federal University, Institute of Management, Economics and Finance, Kazan, 420008, Russia.Email address: kiak6@mail.ru
} 
services and increasing the profit of banks.

Key words: banking information systems, computer banking networks, remote banking services, information technologies of commercial bank management, electronic banking

\section{INTRODUCTION}

The widespread use of information technology has long been considered as necessity. The range of applications of IT sphere is extremely broad. One of the areas of high value is the financial sector. Despite the fact that ten years ago, lending institutions used manual methods of information processing, nowadays almost any bank is obliged to use computers, electronic terminals and electronic communications.

IT helps to maintain external interactions with customers, bank branches, correspondent banks in Russia and in CIS countries, with international banks and other lending institutions.

Computer networks provide a communication function and access to shared resources (file transfer, access to

remote databases and remote task launch). Local and corporate networks unite the various departments of a bank, thus increasing the efficiency of the credit institution and providing a various protective tools measures against unauthorized intrusion to banking information. [1]

Information systems allow to organize remote customer service e.g. Internet banking, card payment system, "Client-Bank" system; interstate, interbank cooperation in the territory of the CIS countries; international settlements, via the SWIFT system. The transfer of information can be conducted via computer, telephone and mobile networks.

The sphere of credit organizations activity is mostly suitable for the introduction of new computer technologies, since almost all the tasks that arise in the course of the bank's operations are easily managed automatically. Fast and smooth processing of significant information flows is one of the main goals of any major financial institution.

\section{METHODS}


The authors consider the

features of information banking systems in Russia and abroad in two main areas of application: remote banking services (RBS) systems and information technologies for the commercial bank management.

RBS are one of the most promising areas for the banking business development. It allows to reduce operating costs significantly, as well as transaction thereby front-office personnel it saves the time of a hick is spent on communication with clients $[2$, $3]$.

\section{RESULTS}

According to the IDC consulting agency data on November 2015, world IT costs have increased in 2016 as in 2013 they have marked the worst dynamics since the recent financial crisis. At year-end 2015 world IT costs have increased by $4 \%$ reaching 2,04 trillion dollars (while in 2013 the growth reached $5 \%$ ) due to the reduction on the key markets such as Chinese and Russian. The volume of the world IT banking market in 2015 reached 179,4 bln dollars. (See fig. 1.5)

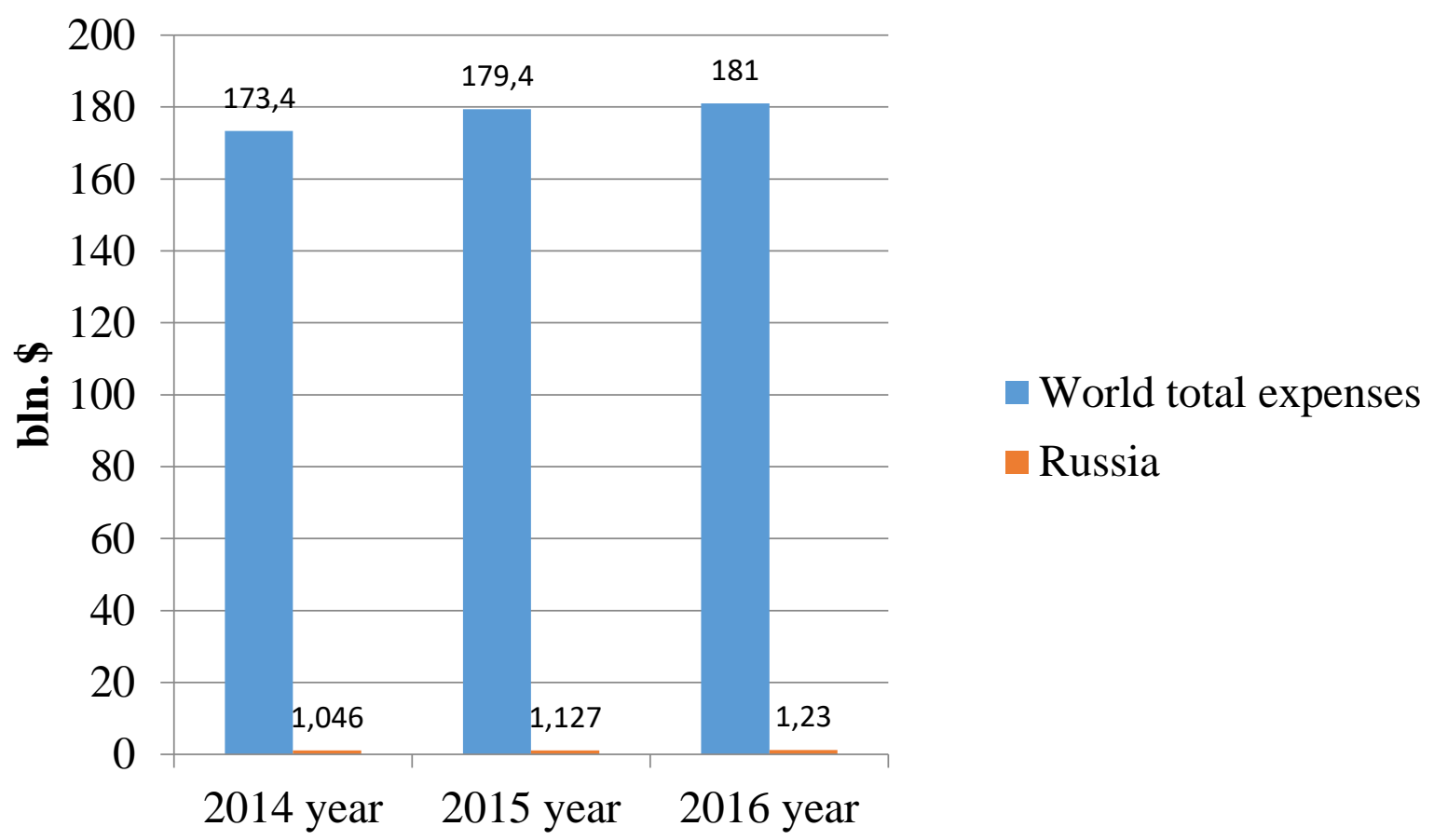

\footnotetext{
${ }^{5}$ Kovalev A. Banking engineering - a new world of finance // Financial director. - 2010. - No. 2.
} 
Fig. 1. The share of expenses for information banking technologies in Russia from the total share of world expenditures

The banks of Asian-Pacific region spend on IT more than other institutions. It is expected that this year their expenses are going to increase by $5,9 \%$ reaching 62,3 bln dollars while next year they will peak 66,5 bln dollars. IT budget of North American banks has increased by $4 \%$ reaching 56,9 bln dollars in 2015 while it reached 59,4 bln dollars in 2016. The lowest indicators are shown by European banks - 0,4\% of growth. According to Forrester Research data banks spend on IT average of 7,3\% from their profit [4].

RBS first was introduced in the USA and was very well developed there. Taking into consideration that almost every American family has a PC, they use the Internet to communicate with their bank rather calling there. Nowadays almost $90 \%$ of American banks provide their customers with RBS [5].

Despite the fact that the remote service system has been invented in the United States, it was widely used in Europe. European Internet banking copied a lot from the US banking system, but also has added something new to it.
Thus, European banks, following the example of their American counterparts, started to provide the planning of personal annual expenses service which is used for payment of public and other compulsory services [6].

Currently, the amount of electronic banking in Western Europe (Germany, Spain, France, the Netherlands), twice as big as amount in the US. In Europe, a new branch in the development of remote maintenance systems is gaining popularity. It is a merger of RBS for individuals and small businesses. In the Russian financial sector, there are different opinions on the need to connect these functions. The prospects of this approach were supported by $57 \%$ of the polled banks, while the remaining $43 \%$ are sure that it is unclaimed [7].

The most important sphere in the development of remote banking services in foreign banks is Internet banking. In Western countries, Internet banking provides the following opportunities [8]:

- payment of bills in real time; 
- crediting;

- cash management.

Along with the webrepresentative offices of traditional banks in America, there is a relatively large number of Internet banks specializing particularly in Internet banking. [9]

The number of traditional banks that provide Internet services 89 . Out of the 100 largest US banks, more than 70 percent provide online services. In the spring of 2017, Markswebb conducted an Internet banking survey in Russia and issued evaluation to 36 credit institutions. Functionality and usability were assessed, and overall scores according to a 100-point scale were also published. In brackets, there are estimates of the functionality of the Internet bank a sing a scale of 0 to 10 points and an assessment of the usability using a scale of 1 to 5 points.

For the past year Moscow Credit Bank, Zapsibcombank, Trust Bank, Russian Standard Bank and Bank of St. Petersburg have left the top ten of the Internet bank rating. The following banks entered the list of the top 10 : Sberbank of Russia, Bank Uralsib, Mail Bank, Raiffeisenbank and Sovkombank. The Internet banks of Binbank (formerly Internet bank of MDM Bank), Tinkoff Bank, Promsvyazbank, Alfa-Bank and VTB, were recognized as the most efficient Internet banks in terms of interface and functionality. Table $1^{6}$

Table. 1.

\section{Rating efficiency of Russian Internet banks}

\begin{tabular}{|l|l|l|}
\hline Place & \multicolumn{1}{|c|}{ Bank } & \multicolumn{1}{|c|}{ Scores } \\
\hline 1 & Tinkoff Bank & $\mathbf{7 7 , 4}(8,2 / 3,9)$ \\
\hline 2 & Promsvyazbank & $\mathbf{7 3 , 5}(7,9 / 3,7)$ \\
\hline 3 & Alfa-Bank & $\mathbf{6 6 , 3}(7,2 / 3,4)$ \\
\hline 4 & VTB & $\mathbf{6 5 , 5}(6,6 / 3,6)$ \\
\hline 5 & Sberbank of Russia & $\mathbf{6 4 , 3}(6,1 / 3,7)$ \\
\hline 6 & Bank Uralsib & $\mathbf{6 4}(6,3 / 3,6)$ \\
\hline
\end{tabular}

${ }^{6}$ Information resource Markswebb [electronic source]: The effectiveness rating of Russian Internet banks. 2017. Access mode: http://markswebb.ru/e-finance/internetbanking-rank-2017/ 


\begin{tabular}{|c|c|c|}
\hline 7 & Mail Bank & $\mathbf{6 3}(7,2 / 3,1)$ \\
\hline 8 & Raiffeisenbank & $62,5(6 / 3,6)$ \\
\hline 9 & Sovcombank*** & $\mathbf{6 1 , 8}(6,8 / 3,2)$ \\
\hline 10 & MKB & $\mathbf{6 1 , 5}(6,3 / 3,4)$ \\
\hline 11 & Zapsibcombank & $\mathbf{6 1 , 3}(6,7 / 3,2)$ \\
\hline 12 & Bank Trust & $\mathbf{6 0 , 2}(6,7 / 3,1)$ \\
\hline 13 & Russian Standard & $\mathbf{5 9 , 1}(6,3 / 3,2)$ \\
\hline 14 & BCS & $\mathbf{5 8 , 6}(6,2 / 3,2)$ \\
\hline 15 & VTB24 & $\mathbf{5 8 , 5}(5,7 / 3,4)$ \\
\hline 16 & Renaissance Credit & $\mathbf{5 8 , 4}(5,4 / 3,5)$ \\
\hline 17 & Bank of St. Petersburg & $\mathbf{5 8 , 2}(6,9 / 2,8)$ \\
\hline 18 & Bank Eastern & $\mathbf{5 7 , 3}(5,7 / 3,3)$ \\
\hline 19 & Bank Absolut & $\mathbf{5 7 , 3}(5,7 / 3,3)$ \\
\hline 20 & Bank of Kazan & $\mathbf{5 4 , 7}(5,9 / 3)$ \\
\hline 21 & Home Credit Bank & $\mathbf{5 4 , 3}(5,6 / 3,1)$ \\
\hline 22 & UBRD & $\mathbf{5 3 , 3}(5,4 / 3,1)$ \\
\hline 23 & UniCredit Bank & $\mathbf{5 3 , 1}(5,6 / 3)$ \\
\hline 24 & Rosselkhozbank & $\mathbf{5 2 , 8}(5,3 / 3,1)$ \\
\hline 25 & AK Bars Bank & $\mathbf{5 2 , 3}(5,2 / 3,1)$ \\
\hline 26 & Bank Avangard & $\mathbf{5 0 , 6}(6,1 / 2,5)$ \\
\hline 27 & MTS Bank & $\mathbf{4 7 , 8}(4,8 / 2,9)$ \\
\hline 28 & Rosbank & $\mathbf{4 5 , 7}(4,1 / 3)$ \\
\hline 29 & Bank Zenit & $\mathbf{4 1 , 6}(3,8 / 2,8)$ \\
\hline 30 & OTP Bank & $\mathbf{4 0 , 5}(3,2 / 2,9)$ \\
\hline 31 & Citibank & $39(3,2$ / 2,8) \\
\hline 32 & Credit Europe Bank & $\mathbf{3 7 , 1}(3,4 / 2,6)$ \\
\hline 33 & Bank Vozrozhdenie & $\mathbf{3 6 , 7}(3,3 / 2,6)$ \\
\hline 34 & Gazprombank & $\mathbf{3 3 , 7}(3,9 / 2,1)$ \\
\hline
\end{tabular}


Internet banking in Russia is more focused on legal clients. For them, based on European counterparts, banks developed such applications as "BankClient" and "Internet-Bank". With their help, businesses and banks save a lot of time on moving documents, filing applications and transferring funds.

The most widespread system of RBS of legal entities is the "Internet client" - it is installed by $90 \%$ of Top 50 and Top 100 banks. The second place is taken by a system of "bank-client" type: $84 \%$ of Top 50 banks and $73 \%$ of Top 100 banks offer it to users. The system of "centralized management of corporate finances of holdings" is used by $40 \%$ of Top 50 banks and $27 \%$ of Top 100 banks [10].

Currently, almost half (46\%) of residents of Russian cities regularly use banking services on the Internet. Over the past year, the Russian Internet banking market has grown by almost 40 $\%$ - up to 590 billion rubles. Taking into account the current trends by 2017 , the domestic Internet banking market can grow by almost three times - to 1.6-1.8 trillion rubles.

In November 2016, the company "Technoserv Consulting"
36

presented the results of a study of the Russian market of remote banking services to retail customers. The survey showed that more than half of banks are satisfied with their RB systems without having the functionality and characteristics that are assigned the highest importance. Priority RBS systems of development of in the near future is the management of personal finance (PFM). $43 \%$ of banks will invest in this area until the end of 2017.

All surveyed banks have official websites on the Internet, but only 10 percent of them have a mobile version that allows users to get information about the bank and its services via a mobile phone conveniently.

Thus, the RBS is a key to the activity of banks both, in Russia and in banks of Western countries, but the development of this system has begun in our country recently. At the same time, the main growth in the turnover of the Russian market of banking non-mobile financial services is forecasted in the next 3-4 years. Thus, the growth of the market of banking non-mobile remote financial services is expected to triple in 5 years. 
However, there are differences between them: Western banks prefer to outsource their organization and services to their RBS, while domestic banks prefer to organize the entire system themselves, spending additional money for the purchase of expensive equipment for RBS systems.

First of all, it should be noted that the development of informatization in the banking sector depends on a large number of normative documents of regulators (the Central Bank of Russia) and federal legislation (for example, the federal law on personal data). On the one hand, reduces various risks, on the other hand, financial organizations are forced to constantly find a balance between the requirements of regulatory documents and the use of technology for business.

Another important feature of banking informatization is special security requirements. Russian standards in the banking sector are already of the same level with international ones, and compulsory compliance with the same PCI-DSS standard obliges our banks to provide protection at a sufficiently high level.

Comparing the work of various Russian banks with US and European banks and assessing the possibility of automating their activities, we have to state there is a lack of unification and standardization of banking technologies in Russia [11], which causes problems with training personnel with information technology work on common requirements.

Technologies for performing the above mentioned banking operations differ in various banks. There is a discrepancy between the goals and functions for the same automated sections, the diversity in the technology of documenting of the same operations, the different forms of reporting, the frequency of their presentation in different areas of management connected to the specialization of employees. This led to the appearance of a large number of software tools on the market that provide partial automation of banking activities.

In many banking information systems only the most basic, most important tasks are automated according to system developers ' point of view of. This can be explained by the absence of some services factoring, leasing, card services; but there are management tasks that are solved in any bank which, as a 
rule, are absent in most domestic banking information systems, for example, automated loan portfolio quality analysis, forecasting and planning of credit resources.

In order to determine the current world system-technical trends in the development of information technology in the banking sector, we have to analyze the most widely known and widely spread integrated banking automation systems offered on the international market on a regular commercial basis. Partnership Leaders are: IBM (USA), DEC (USA), Siemens (Germany), Oliwetti (Italy), Bull (France).

- Analysis of the software products of the Russian market (Sistema, BANKIR, ELBRUS, DORA, SADKO, Mercury SOFT, etc.) shows that the practical allocation of subsystems and

Table 2. Differences in the security of banking information systems in Russia and the United States

\begin{tabular}{|l|l|l|l|}
\hline & & \multicolumn{1}{|c|}{ Russia } & USA \\
\hline 1 & $\begin{array}{l}\text { Assessment for strategic } \\
\text { risks }\end{array}$ & $\begin{array}{l}\text { FSTEC (Federal Service for } \\
\text { Technical and Export Control) } \\
\text { has no publications. }\end{array}$ & No problem \\
\hline 2 & $\begin{array}{l}\text { Availability of } \\
\text { methodological } \\
\text { documents for protection }\end{array}$ & $\begin{array}{l}\text { In Russia there is practically } \\
\text { no control after the } \\
\text { certification of the system, as }\end{array}$ & $\begin{array}{l}\text { NIST (National Institute } \\
\text { of Standards and } \\
\text { Technology (USA)) has }\end{array}$ \\
\hline
\end{tabular}

tasks in the integrated BIS takes into account their grouping simultaneously using three characteristics:

- management structure;

- transformation of resources;

- management functions.

\section{DISCUSSION}

It should be noted that an important place in the functioning of banking information systems is taken by their protection. We came to the conclusion that Russia and the United States have a number of differences in the security of banking information systems (BIS), which we presented in Table 2. 


\begin{tabular}{|l|l|l|l|}
\hline \multicolumn{2}{|l|}{} & $\begin{array}{l}\text { well as between the various } \\
\text { stages of its certification. }\end{array}$ & $\begin{array}{l}\text { already produced more } \\
\text { than one hundred special } \\
\text { publications on this } \\
\text { subject. }\end{array}$ \\
\hline 3 & $\begin{array}{l}\text { The result of the } \\
\text { implementation of the } \\
\text { protection system and its } \\
\text { attestation }\end{array}$ & $\begin{array}{l}\text { US government agencies } \\
\text { are accompanied } \\
\text { throughout the life cycle } \\
\text { of the existence of their } \\
\text { information systems. And } \\
\text { even at their last stage, } \\
\text { decommissioning, NIST } \\
\text { offers its } \\
\text { recommendations. }\end{array}$ \\
\hline
\end{tabular}

The first difference is the risk assessment. Until recently, it was not common in Russia to entrust owners of information systems with assessment of risks. A set of protective measures was determined, and it had to be implemented under any circumstances. At the same time, additional information systems (mobile devices, wireless technologies) were either banned, or regulators ignored them. Now the situation is gradually change, operators and owners of information systems are allowed to simulate the risk by themselves.
The second difference in the total absence strategic risks assessment in Russia and other input data. Personnel absenteeism, weak communication channels, lack of financial resources, territorial distribution, obligatory shift to cloud computing, the need for interaction with foreign organizations. [12]

The third difference is the huge number of methodological documents on the protection of one or another information technology or the implementation of a particular protective process. NIST (National Institute of Standards and Technology (USA) has already issued more than 100 special 
publications on this issue.) FSTEC (the Federal Service for Technical and Export Control) has no publications, given the shortage of specialists, especially in the regions, the methodological assistance of the regulator is not enough. Central Bank of Russia Federation is trying to correct the situation.

The fourth difference is what happens after the implementation of the protection system and its attestation. In Russia there is practically no control after the certification of the system, as well as between the various stages of its certification. In the US, the situation is different: there are recommendations for building a process to monitor the level of security, responding to incidents, raising staff awareness, patch management, etc. In other words, US government agencies are accompanied throughout the life cycle of their information systems. And even at their last stage, decommissioning, NIST offers its recommendations, for example, SP80088 Guidelines for Media Sanitization (a guide to destroying the carriers of protected information).

Thus, the main trends for both domestic and foreign IBS are improving the quality and reliability of the products and offered services, increasing the speed of settlement operations, and organizing electronic access of customers to banking products. In the future it will contribute to the active introduction of the latest achievements in the field of computer technology, network and information technologies, methods of information protection and data processing into banking sphere.

\section{SUMMARY}

In this research, the topic of using information technologies in banking has been considered. Within the framework of this topic it was proved that the transition to the use of modern technologies is justified not only due to the additional functionality that is absent in the old technologies, or due to the increase the productivity of the system as a whole, but also often due to a significant reduction in the regular costs of the production process accompanying. Evolutionary development of the banking sector changes the requirements for the decision-making process, which entails changing the requirements for the surveyed information, the development of 
processing methods, and the visualization methods. Not only the volume of processed information has increased, but its qualitative composition also has changed. Analytical information is gaining importance in banking characterizes the objects and entities involved in the business process.

\section{CONCLUSIONS}

Putting the survey, the authors accomplished the following tasks:

- types of information banking technologies have been considered;

- have been considered the features of banking information systems in Russia and abroad;

- have been analyzed modern trends in the development of information technology in Russian credit institutions.

The research allowed us to come to a conclusion that the IT play a dominant role in the new client attraction and integration. The issues concerning banking IT services are of great importance and should be thoroughly considered by top management of financial institutions.

Information technology directly determine the possibility of organizing business development and the improvement of internal processes and customer service system.

In the consideration of the foregoing, in order to improve the quality of services and the profit of banks, the following IT directions are proposed:

- optimization the banking services and improvement of the customer service quality;

- introduction of innovative banking technologies;

- implementation of service standards quality;

- increase of domestic banks expenses for IT infrastructure.

A key approach to IT management is the need for ongoing improvement and optimization. Another component of the proper IT organization and management is the documented reflection of the main aspects of its introduction and operation. At the same time, during the process of IT infrastructure improvement and new technologies introduction, the bank should also pay increased attention to the security of its information systems.

\section{ACKNOWLEDGEMENTS}


The work is performed according to the

Russian Government Program of

Competitive Growth of Kazan Federal University.

\section{REFERENCES}

Zhiwei Zhu, Larry Scheuermann, Billy

J. Babineaux Jr, (2004) "Information network technology in the banking industry", Industrial Management \& Data Systems, Vol. 104 Issue: 5, pp.409417, [Electronic resource]: https://doi.org/10.1108/0263557041053 7499.

Hamdan O. Alanazi, Prof. Dr. Patrice Boursier (2010). Secured Mobile Banking System with an Efficient Bandwidth and Prevent the Delay

Time // Journal of computing, Volume 2, Issue 10, October 2010. [Electronic resource]:

https://ru.scribd.com/document/430927

52/Secured-Mobile-Banking-Systemwith-an-Efficient-Bandwidth-and-

Prevent-the-Delay-Time

Kovalev A. Banking engineering - a new world of finance // Financial director. 2010. - No. 2.

Khubaev N.G. Information systems in the activity of economic objects. I
Khubaev NG. - M: Publishing Center March, 2012.

Feofanov V.Yu. Preparation for automation: the human factor / / Handbook of personnel management. № 5, 2008, p. 10-16.

Yasenev V.N. Automated information systems in the economy: Teachingmethodical manual .- N. Novgorod: UNN, 2009. -170 s

Banking Information Technologies. 2015. [Electronic resource]: http://yourlib.net/content/view/12905/1 $53 /$

Professional financial journal [electronic resource]: What is remote banking service. - 2015. [Electronic resource]: http://www.pfj.ru/rubrica/120913/602/

Shumaila Yousafzai, John Pallister and Gordon Foxall (2009). Multidimensional role of trust in Internet banking adoption // The Service Industries Journal. Vol. 29, No. 5, May 2009, 591-605. [Electronic resource]: https://www.researchgate.net/publicatio n/247523936_Multidimensional_role_o f_trust_in_Internet_banking_adoption Information bank portal [Electronic resource]: Access mode: www.banki.ru 
Pyun Ch.S., Scruggs L., Nam K. (2002).

Internet banking in the U.S., Japan and

Europe // Multinational Business

Review, Fall 2002. No 2, pp. 73-82.

[Electronic

resource]:

https://www.questia.com/library/journal

/1P3-146682121/internet-banking-in-

the-u-s-japan-and-europe

Yusupova L.M, Nikonova T.V, Nugayev

F.S., Formation of competitive advantages of banking systems of Russia, China and the United States in the concept of National Interest//Journal of Economics and Economic Education Research. - 2016. - Vol.17, Is.SpecialIssue2. - P.150-156. 